\title{
Teenagers Attitudes and Practices of Dating in Morocco: Fez City as a Case Study a Pilot Study
}

\author{
S. Elkinany ${ }^{1}$, K.Elkinany ${ }^{2}$, B.Zarrouq ${ }^{3}$, F. Amrani Zerrifi ${ }^{4}$ \\ ${ }^{1} \mathrm{PhD}$ Student, Sidi Mohamed Ben Abdellah University \\ College of Literature and Human Sciences \\ ${ }^{2} \mathrm{PhD}$ Student, Sidi Mohamed Ben Abdellah University, Faculty of Science Fez \\ ${ }^{3} \mathrm{PhD}$ Student, Sidi Mohamed Ben Abdellah University \\ School of Medicine and Pharmacy \\ ${ }^{4}$ Professor, Sidi Mohamed Ben Abdellah University \\ College of Literature and Human Sciences
}

\begin{abstract}
Dating is a far-flung practice among younger populations. Regardless of its religious and cultural incrimination in Arab and Muslim countries, dating represents a fertile arena to study the various discourses governing male female relationships in Morocco. In this regard, a pilot study was conducted among a sample of 100 adolescents in Fez city. An anonymous self-administered questionnaire was used to illicit teenagers' attitudes and practices of dating. The mean age of the participants was 16, 62 $\pm 2,24$. Most participants belonged to low-income families $(64,4 \%)$ and lived with both parents $(83,2 \%)$. The findings revealed that most participants $(60,6 \%)$ had a dating experience, which lasted at least a month $(58.2 \%$ for males, and $41.8 \%$ for females), with a significance $\left(p=10^{-2}\right.$, OR=0.49). Meanwhile, less males than females agreed that their religiosity hampered them from the practice of dating $\left(41 \%\right.$ versus $\left.59 \%, p=10^{-2}\right)$. Concerning daters' attitudes, more males expressed their refusal to marry a partner who had a previous dating experience $(65.2 \%)$ with a significance of $p=10^{-3}$. Multi-variate analyses showed that Participants educational level and religiosity were indeed protective factors for Moroccan males and females teenagers. Holding negative attitudes towards female daters however proved a risk factor endangering teen dating relationships. Overall, most teenagers' practices and attitudes reflected their conflicting perceptions of modernity, religion, and patriarchy.
\end{abstract}

Keywords: Teenagers' attitudes and practices__Dating _ Morocco (Fez city).

\section{Background}

Dating prevails in adolescence as teens look up to gratify their sexual desires using the pretext of friendships or love relationships. From adults' angle, adolescents' dating may not be viewed as a serious bounding; meanwhile, studies proved that early dating experiences have a pivotal role in shaping youth longterm understanding of personal relationships [1]. Generally speaking, much of the existing literature on dating focused on adolescent sexual behaviour and overlooked important aspects of teen dating and their effects on adults relationships. Lately, there is a growing tendency towards studying the quality of adolescents 'relationships and partners socio-demographic characteristics. In western countries, researchers 'attentions have even shifted towards the examination of relationships models outside the heterosexual paradigm [2].

In Arab and Muslims societies, little is known about teen dating. In fact, dating relationships are not welcome practices in Morocco as they disturb the traditional role of females that is reproduction. Daters especially females are placed at higher risks of defamation in case of virginity loss because of Moroccans' obsession over physical chastity [3]. In fact, understanding teenagers' attitudes and practices of dating in Morocco may help experts assess relationships quality and find the associations between gender hostility attitudes and dating violence. Unfortunately, research on this field of study is so limited regarding the sensitive nature of this issue. Therefore, the present study came to fill this gap and explore Moroccan daters' attitudes and practices while shedding the light on the multiple ideologies adopted by younger generations. 


\section{Methods}

\subsection{Study Sites}

The study was carried out from June to July 2015 in two public secondary schools (a middle and a high school). The middle school was located in a poor district within Fez city (Fez Jdid); whereas, the high school was $21.7 \mathrm{~km}$ away from the city. The schools, in which the process of data collection took place, were randomly selected.

\subsection{Procedures}

The questionnaire collected information on participants' socio-demographic characteristics, (mainly sex, age, participants as well as parents' education, parents' marital status, and family income).Data on participants' lifetime dating experience, dating status, and dating attitudes were also included. The anonymous selfadministered questionnaires were distributed in the classrooms during a regular class period, and were filled by participants in the absence of teachers. The Participation was voluntary and students stated their oral consent before filling the forms. The Researchers and investigators in charge of questionnaires distribution indeed provided explanations on the filling instructions and to the participants when needed. Almost all questions on dating practices were of a dichotomous response type (yes-no); while, the attitudes required agreement or disagreement expressions.

\subsection{Statistical analysis}

The data entry stage started immediately after data collection. Data were entered into MS Windows Excel in the form of codes, and transferred to the Statistical Package for EPI INFO software version 7 (free downloaded from internet). Data analysis involved descriptive as well as inferential statistics. A simple descriptive analysis was done for the variables of interest. Odds ratios, along with 95\% confidence intervals, were calculated. Differences in proportions were assessed by the Chi-square test. $\mathrm{P}$ values of $<0.05$ were considered as statistically significant. Variables with significant $\mathrm{p}$ values were entered into a regressive logistic model to predict the quality of dating relationships among the studied population.

\section{Results}

\subsection{The Socio-demographic Characteristics:}

The study was conducted in summer 2015 among 100 secondary school students aged 14-20 years. The mean age of the participants was 16, $62 \pm 2,24$. The sample was equally divided between males and females (50\% were males and 50\% were females). Equally important, all participants were Muslims. Regarding education, about $53 \%$ of participants were high schoolers; whereas, $47 \%$ were middle school students. Moreover, as many as $43 \%$ of students' fathers completed a primary level; while, $42 \%$ of mothers were illiterate. Most participants' parents 86, $9 \%$ were married, and 83,2 \% lived with both parents. All the same, 64,4\% belonged to low-income families.

\subsection{Dating Attitudes}

\subsubsection{Religiosity and Dating:}

TABLE I: Religiosity as an Obstacle to Dating

\begin{tabular}{lcccc}
\hline & \multicolumn{4}{c}{ My Religiosity is an Obstacle to Dating } \\
\hline & Males & Females & P & OR \\
\hline I agree & $41 \%$ & $59 \%$ & & \\
\cline { 1 - 3 } I Disagree & $81.8 \%$ & $18.2 \%$ & & 0,15 \\
\hline
\end{tabular}

As indicated by the table (1) findings, about $59 \%$ of females considered religiosity as an obstacle to dating, contrasted to $41 \%$ of males. A large number of males $(81.8 \%)$ on the other hand disagreed with the abovestatement. The expressed attitudes reveal that the notion of conservatism was positively associated with the female gender $\left(\mathrm{p}=10^{-2}, \mathrm{OR}=0.15\right)$. 


\subsubsection{Attitudes About Male and Female Daters}

TABLE II: Female Daters and Respect

\begin{tabular}{|c|c|c|c|c|}
\hline & \multicolumn{4}{|c|}{ Female daters are unrespectable } \\
\hline & Males & Females & $\mathrm{p}$ & OR \\
\hline I agree & $52.9 \%$ & $47.1 \%$ & & \\
\hline I disagree & $46.9 \%$ & $53.1 \%$ & 0.3 & 1.27 \\
\hline
\end{tabular}

Table (2) showed that $52.9 \%$ of male participants had a negative impression of female daters, compared to $47.1 \%$ of females. Almost $53.1 \%$ of females however reported their disagreement. Overall, $\mathrm{p}$ values were not significant because the opinions of male and female participants were so close.

TABLE III: Male Daters and Virility

\begin{tabular}{lcccc}
\hline & \multicolumn{4}{c}{ Males who date many girls are virile } \\
\cline { 2 - 3 } & Males & Females & P & OR \\
\hline I agree & $61.9 \%$ & $38.1 \%$ & & \\
\hline I disagree & $46.8 \%$ & $53.2 \%$ & 0,1 & 1.84 \\
\hline
\end{tabular}

In response to "whether males who date several girls are virile", a large number of male participants (61.9\%) agreed. Contrariwise, $53.2 \%$ of females disagreed. No association was found; nevertheless, the high percentage of males adopting such an attitude hints on their problematic perception of virility and manhood.

TABLE IV: Female Daters and Marriage

\begin{tabular}{|c|c|c|c|c|}
\hline \multicolumn{5}{|c|}{ Female daters are unmarriageable } \\
\hline & Males & Females & $\mathrm{P}$ & OR \\
\hline I agree & $65.2 \%$ & $34.8 \%$ & \multirow[b]{2}{*}{$10^{-3}$} & \multirow[b]{2}{*}{3.35} \\
\hline I disagree & $35.8 \%$ & $64.2 \%$ & & \\
\hline
\end{tabular}

As displayed in Table (4), many male participants (65.2\%) agreed that female daters are unmarriageable, contrasted with $35.8 \%$ of male opponents. Moreover, $64.2 \%$ of females stated their disapproval. In fact, the statement was highly associated with the male gender $\left(\mathrm{p}=10^{-3}\right)$, which reflected males' denigration to female daters.

TABLE V: Relationships and male pleasing

\begin{tabular}{lcccc}
\hline & \multicolumn{4}{c}{ Dating relationships work best when girls please boys } \\
\cline { 2 - 3 } & Males & Females & P & OR \\
\hline I agree & $65.2 \%$ & $34.8 \%$ & $10^{-3}$ & 3.18 \\
\hline I disagree & $37 \%$ & $63 \%$ & & \\
\hline
\end{tabular}

In response to whether dating works best when girls please boys, a large number of males (65.2\%) adopted favourable attitudes. About $63 \%$ of females expressed their opposition. Such an attitude was positively associated with male participants and the inverse for females $\left(\mathrm{p}=10^{-3}, \mathrm{OR}=3.18\right)$.

\subsection{Dating Practices}

\subsubsection{Relationship status}

TABLE VI: Lifetime dating experience

\begin{tabular}{ccccc}
\hline & \multicolumn{4}{c}{ Have you ever dated somebody? } \\
\cline { 2 - 5 } & Males & Females & $\mathrm{p}$ & OR \\
\hline Yes & $58.2 \%$ & $41.8 \%$ & $10^{-2}$ & 0.49 \\
\hline No & $40.9 \%$ & $59.1 \%$ & & \\
\hline
\end{tabular}

The above findings showed that the dating practice remained relatively higher in males $(58.2 \%)$ than in females (41.8\%). Concerning the participants who denied being in a dating relationship before, the percentage of 
females exceeded that of males, $(59.1 \%$ vs. $40.9 \%)$. In fact, the lifetime dating experience was positively associated with males and negatively associated with females $\left(\mathrm{p}=10^{-2} ; \mathrm{OR}=0.49\right)$.

TABLE VII: Current Dating Experience for at least 1 Month

\begin{tabular}{lcccc}
\hline & \multicolumn{4}{c}{ I am currently in a dating relationship for at least 1 Month } \\
\cline { 2 - 4 } & Males & Females & $\mathrm{p}$ & OR \\
\hline Yes & $48.9 \%$ & $51.1 \%$ & & 0.4 \\
\hline No & $54.3 \%$ & $45.7 \%$ & $0.4 \%$ & 1.24 \\
\hline
\end{tabular}

The table indicated that the number of female middle schoolers who admitted being currently in a dating relationship for at least 1 month exceeded the number of their male classmates $(51.1 \%$ vs. $48.9 \%)$. Equally important, about $54.3 \%$ of male secondary school students said they were not in a recent relationship for at least 1 month. No association was detected.

TABLE VIII: Relationship Duration

\begin{tabular}{lcc}
\hline \hline & \multicolumn{2}{c}{ I am/ was in a dating relationship for } \\
\cline { 2 - 3 } & males & females \\
\hline 1 month & $47.6 \%$ & $52.4 \%$ \\
\hline from 1 to 6 months & $54.5 \%$ & $45.5 \%$ \\
\hline 1 year & $70 \%$ & $30 \%$ \\
\hline 2 years & $25 \%$ & $75 \%$ \\
\hline 3 years or more & $60 \%$ & $40 \%$ \\
\hline \hline
\end{tabular}

The majority of female secondary school students (75\%) were in dating relationships for a period of two years, followed by $52.4 \%$ of girls who were in relationship for one month. in addition, about $70 \%$ of males were in a dating relationship for a year; while, $60 \%$ were in a dating relation for more than three years. Indeed, the table indicated that males started relationships earlier than females.

\subsection{Logistic regression Analysis}

Variables with significant $\mathrm{p}$ values were entered into a regressive logistic model to predict the quality of dating relationships among the studied population. The independent variable of sex was assessed in relation to participants' educational levels, their attitudes about dating relationships and female daters.

TABLE IX: Logistic Regression Analysis

\begin{tabular}{|c|c|c|c|c|}
\hline \multirow[t]{2}{*}{ Most Significant Variables } & \multirow[t]{2}{*}{ OR } & \multirow[t]{2}{*}{$\mathrm{P}$} & \multicolumn{2}{|c|}{$95 \%$ IC } \\
\hline & & & Inferior & Superior \\
\hline Participants' Education level & 0.25 & $10^{-3}$ & 0.08 & 0.70 \\
\hline Dating Works best when Girls please boys & 1.97 & $10^{-3}$ & 1.19 & 3.24 \\
\hline Dating as an obstacle to religion & 0.29 & $10^{-3}$ & 0.14 & 0.60 \\
\hline Female daters are unmarriageable & 1.93 & $10^{-2}$ & 1.17 & 3.19 \\
\hline
\end{tabular}

Multi-variate analyses showed that Participants educational level and religiosity were indeed protective factors for Moroccan males and females teenagers. Holding negative attitudes towards female daters however proved a risk factor endangering teen dating relationships. Bearing in mind that a high percentage of males adopted such negative attitudes, the assumption of male perpetration in dating relationship is possible.

\section{Discussion}

To recapitulate, the present study explored Moroccan teenagers' attitudes and practices of dating in Fez city. The notion of conservatism was high among females and proved a preventive factor against lifetime dating experiences. Nevertheless, more females than males stated that they were in current dating relationships, which was incompatible with their previous statements about religiosity. Males on the other hand did not consider their religiosity as an impediment to dating as exhibited in their relationships durations; despite that, they held negative and denigrating attitudes about female daters. 
Females' conservatism can be explained by socialization. Moroccan females are brought up to conform with social rules and conventions. The very social construction of femininity is reinforced by religious and cultural calls for modesty and honor. In fact, female sexuality is perceived as a great menace to morality and order. Thus, it must be controlled, curbed or at least regulated. No wander social mechanisms such as religion, politics and traditions have been exploited to achieve this task on whatever costs. This latest emblems an unravelled weapon for legitimizing culture's control over female sexuality. In other words, females opting for religion as an obstacle to dating does not necessary reflect their high degree of religiosity; It does rather hint on their full internalization of social norms. Soumaya Naamane Guessous, a Moroccan sociologists and the author of Au Delà de Toute Pudeur (2007) states that femininity is essentiatized to a fragile membrane that girls ought to preserve till marriage if they'd like to survive respectfully.[4] Contrariwise, the social construction of masculinity does correlate between the idea of manhood and virility, as was displayed in males attitudes. To say otherwise, that the religious discourse of preserving chastity and honesty before marriage is not invoked among males.

Males' negative attitudes about female daters are actually a strong predictor of potential dating violence. Several studies found a strong relationship between tolerance of traditional gender roles and acceptance of violence [5] [6] [7] [8]. Equally important, an extensive body of literature proved that males are more likely than females to believe in attitudes promoting violence against women [9] [10] [11] [12] [13] [14] [15] [16] [17] [18]. Nayak et al. 2003 argues that less gender attitudes result in less violence. [19] In our study, the majority of males agreed that relationships work best when girls please boys. Margolis (1998) explains that by media socialization, which has generated the belief that women ought to prioritize male requirements over their own. [20] Finally, education is a protective factor against unhealthy dating. Naved and Persson, (2005) found that less violence was detected among males who received higher education than secondary level. [21] Likewise, education beyond secondary level protects women against violence, and reduce its acceptance. [22]

\section{Conclusion and Limitations}

In conclusion, Moroccan daters' claims of conservatism are in conflict with their practices. Female daters are indeed disadvantaged by the practice of dating in the presence of males denigrating attitudes. At last, the small sample size, as well as the sensitivity of the topic are major limitations of the presented study; eventually, further research is required on the subject matter.

\section{Acknowledgements}

This work would not have been possible without the guidance and the cooperation of several individuals, and institutions. We are grateful for Sidi Mohamed ben Abdellah college of Literature and human sciences administration for providing researchers with authorizations to facilitate the process of data collection within the schools. We would like also to thank the secondary schools headmasters and teachers for their help, not to mention students for filling the four-page questionnaire.

\section{References}

[1] Sorensen, S. (July 2007). Adolescent romantic relationships. Research FACTS and Findings [Fact Sheet]. ACT for Youth Center of Excellence. pp. 1-4. Available : http://www.actforyouth.net/resources/rf/rf_romantic_0707.pdf

[2] Furman, W. The emerging field of adolescent romantic relationships.Current directions in Psychological Science, vol.11, pp. 177-180, 2002. http://dx.doi.org/10.1111/1467-8721.00195

[3] Mernissi, F. Beyond the Veil: Male-Female Dynamics in a Muslim Society, $3^{\text {rd }}$ ed , U.S.A Indiana University Press, 1987, ch.1, pp. 6-29.

[4] Guessous, S. Au Dela de Toute Pudeur. Casablanca, Morocco: Edition Eddif, 2007, ch 1., p.15-31.

[5] Berkel, L. and B. Vandiver, and A. Bahner. Gender role attitudes, religion, and spirituality as predictors of domestic violence attitudes in White college students. Journal of College Student Development, vol. 45, pp.119-133, 2004. http://dx.doi.org/10.1353/csd.2004.0019

[6] Flood, M. and B. Pease. Factors influencing attitudes to violence against women. Trauma Violence Abuse. vol. 2, pp.125-42, 2009.

http://dx.doi.org/10.1177/1524838009334131 
[7] Good, G. E., M. J. Heppner, T. L. Hillenbrand-Gunn and L. F. Wang. Sexual and psychological violence: An exploratory study of predictors in college men. Journal of Men's Studies, vol. 4, pp. 59-71, 1995.

[8] Simonson, K. and L. M. Subich. Rape perceptions as a function of gender-role traditionality and victim perpetrator association. Sex Roles, vol.40, pp. 617-634, 1999.

http://dx.doi.org/10.1023/A:1018844231555

[9] Anderson, I. and V. Swainson, Perceived motivation for rape: Gender differences in beliefs about female and male rape. Current Research in Social Psychology, vol.6, pp.107-122, 2001.

[10] Chng, C.L. and S. Burke, An assessment of college students' attitudes and empathy toward rape. College Student Journal, vol.33, pp. 573-583, 1999.

[11] Cowan, G. Beliefs about the causes of four types of rape. Sex Roles, vol. 42, pp.807-823, 2000. http://dx.doi.org/10.1023/A:1007042215614

[12] Ewoldt, C. A., C. M. Monson and J. Langhinrichsen-Rohling, Attributions about rape in a continuum of dissolving marital relationships. Journal of Interpersonal Violenc , vol.15, pp.1175-1182, 2000. http://dx.doi.org/10.1177/088626000015011004

[13] Hinck, S. S. and R. W. Thomas, Rape myth acceptance in college students: How far have we come? Sex Roles, vol.40, pp. 815-832, 1999. http://dx.doi.org/10.1023/A:1018816920168

[14] Lee, J., E. C. Pomeroy, S.-K.Yoo and K. T. Rheinboldt, Attitudes toward rape: A comparison between Asian and Caucasian college students. Violence Against Women, vol.11, pp. 177-196, 2005. http://dx.doi.org/10.1177/1077801204271663

[15] West, A.and M. L. Wandrei, Intimate partner violence: A model for predicting interventions by informal helpers. Journal of Interpersonal Violence, vol.17, pp. 972-986, 2002. http://dx.doi.org/10.1177/0886260502017009004

[16] White, B. H. and S. E. R. Kurpius, Attitudes toward rape victims: Effects of gender and professional status. Journal of Interpersonal Violence, vol.14, 989-995, 1999. http://dx.doi.org/10.1177/088626099014009006

[17] Matos M. Violência nas relações de intimidade: estudo sobre a mudança psicoterapêutica na mulher. Dissertação. Braga: Universidade do Minho; 2006.

[18] Saavedra R. and C. Machado, Programas de prevenção primária da violência nos relacionamentos íntimos: uma revisão sistemática da prática internacional e portuguesa. Coimbra: Almedina; 2012.

[19] Nayak, M. B., C. A. Byrne, M. K. Martin and A. G. Abraham, Attitudes toward violence against women: A crossnation study. Sex Roles, vol.49, pp. 333-342, 2003. http://dx.doi.org/10.1023/A:1025108103617

[20] Margolis, D. Culturally sanctioned violence against women: A look at attitudes toward rape. Unpublished doctoral dissertation, Graduate School of Education, Boston College, Boston, MA, 1998.

[21] Naved, R. T. and L. A. Persson, Factors associated with spousal physical violence against women in Bangladesh. Studies in Family Planning,vol. 36, pp. 289-300, 2005. http://dx.doi.org/10.1111/j.1728-4465.2005.00071.x

[22] World Health Organization. WHO Multi-country Study on Women's Health and Domestic Violence against Women, 2005. Available :

[23] http://www.who.int/gender/violence/who_multicountry_study/summary_report/summary_report_English2. 